\title{
Prognostic importance of ophthalmic manifestations in childhood leukaemia
}

Departments of

Ophthaimology, Brown

University, USA and

St Luke's International

Hospital, Japan

K Ohkoshi

Departments of Ophthalmology, Brown University and Rhode Island Hospital, USA W G Tsiaras

Correspondence to: Dr Kishiko Ohkoshi, Department of Ophthalmology, St Luke's International Hospital, 9-1, Akashi-cho, Chuo-ku, Tokyo, 104, Japan.

Accepted for publication 21 May 1992

\author{
Kishiko Ohkoshi, William G Tsiaras
}

\begin{abstract}
In order to assess the systemic prognosis of children with leukaemic ocular involvement, 63 of 131 patients admitted to hospital with acute leukaemia were evaluated ophthalmically. A total of 28 of 63 showed ophthalmic involvement and were followed up for up to 84 months. Twenty seven of 28 patients $(96.4 \%)$ died within 28 months after the onset of ocular involvement and within 83 months after the onset of leukaemia. The 5 year survival rate of patients with ophthalmic manifestations was $21 \cdot 4 \%(6 / 28)$. This survival rate was significantly lower than that of those who lacked ophthalmic manifestations (16/35: $45 \cdot 7 \%$, $p<0.05)$. All of the patients with ophthalmic manifestations had either bone marrow relapse or central nervous system leukaemia. The prognosis was related to risk factors such as central nervous system leukaemia or bone marrow relapse in most cases.
\end{abstract}

(Brf Ophthalmol 1992; 76: 651-655)

Though numerous studies ${ }^{1-8}$ have shown ocular involvement in leukaemia very few have suggested a relationship between the ocular findings and systemic prognosis. ${ }^{124910}$ In the era before antileukaemic therapy retinopathy was believed to be of no prognostic significance in acute leukaemia. ${ }^{12}$ Since modern chemotherapy was introduced, it has prolonged the survival period and provided a possibility of cure in acute leukaemic children. Modern chemotherapy, however, has paradoxically increased the incidence of leukaemic cell infiltration especially to the central nervous system. There have been no studies, however, showing a correlation between ophthalmic findings in leukaemia and the systemic course of leukaemia in patients treated with chemotherapy. In this study we investigated the prognosis of patients with ophthalmic findings to see if they played a role in predicting the prognosis of leukaemia.

\section{Materials and methods}

From January 1972 to June 1987, 131 children with acute leukaemia were treated and followed at the St Luke's International Hospital (Tokyo) and Juntendo University Hospital. Sixty three of the 131 patients were referred to the department of ophthalmology by paediatricians. Forty seven were referred when signs or symptoms of ocular abnormalities were present and 16 were referred as having risk factors such as central nervous system leukaemia, severe thrombocytopenia, or marked leucocytosis. Twenty eight patients (14 male), showed leukaemic ophthalmic involvement at some point during the course of their disease. Six patients showed ophthalmic involvement at the onset of leukaemia and 22 at the time of either bone marrow or central nervous system relapse. Four patients had isolated ocular leukaemic relapse. The observation period for the 131 children was more than 5 years from the onset of disease for those children who survived. Eighty seven had acute lymphoblastic leukaemia, and 44 had acute nonlymphoblastic leukaemia. In the 28 patients with ophthalmic manifestations, 17 had acute lymphoblastic leukaemia, and 11 had acute nonlymphoblastic leukaemia. The age of the patients ranged from 3 months to 12 years with an average of 6.9 years. The diagnosis of the ophthalmic involvement was made after examination with both direct and indirect ophthalmoscopy and slit-lamp examination.

Among the referred cases 19 patients who had ocular abnormalities which were not directly linked to leukaemia such as infection, side effects of chemotherapy, and/or refractive errors, were excluded. One patient with retinal haemorrhage during remission was excluded because it was felt that a liver disorder was the main cause of the haemorrhage. Two patients with subconjunctival haemorrhage which occurred during remission were also excluded. All patients were treated, according to the protocol of the Tokyo Children's Leukemia Study Group, with multiple chemotherapeutic drugs and in some instances prophylactic irradiation for central nervous system leukaemia. None of the patients had bone marrow transplantation; no patients refused treatment; no patient died from causes other than complications of leukaemia.

In this study, onset of disease was defined as the earliest time that either symptoms or signs were noted; this applied to the underlying leukaemia and to ophthalmic manifestations.

\section{Results}

We classified ophthalmic involvements into two major categories: (1) direct leukaemic infiltration

Table 1 Number of the patients with ocular manifestation

\begin{tabular}{lcc}
\hline & $\begin{array}{l}\text { Acute } \\
\text { lymphoblastic } \\
\text { leukaemia }\end{array}$ & $\begin{array}{l}\text { Acute } \\
\text { non-lymphoblastic } \\
\text { leukaemia }\end{array}$ \\
\hline $\begin{array}{l}\text { Optic nerve infiltration } \\
\begin{array}{l}\text { Uveal infiltration } \\
\text { Orbital infiltration } \\
\text { Neuro-ophthalmic sign of } \\
\text { central nervous system }\end{array}\end{array}$ & $5(5)$ & 0 \\
$\begin{array}{l}\text { leukaemia } \\
\text { Retinal haemorrhages and } \\
\text { vascular changes }\end{array}$ & $11(11)$ & $3(2)$ \\
\begin{tabular}{l} 
Total \\
\hline
\end{tabular} & $8(5)$ & $5(2)$ \\
\hline
\end{tabular}

( ) central nervous system leukaemia

Ten had more than two abnormalities 
Table 2 Survival of patients with optic nerve infiltration

\begin{tabular}{|c|c|c|c|c|c|}
\hline \multirow[b]{2}{*}{ Type } & \multirow[b]{2}{*}{ Ophthalmic findings } & \multirow[b]{2}{*}{$\begin{array}{l}\text { Treatment for } \\
\text { the eye }\end{array}$} & \multicolumn{2}{|l|}{ Survival (months) } & \multirow[b]{2}{*}{$\begin{array}{l}5 \text { year } \\
\text { survival }\end{array}$} \\
\hline & & & $\begin{array}{l}\text { After ophthalmic } \\
\text { manifestation }\end{array}$ & $\begin{array}{l}\text { After onset } \\
\text { of leukaemia }\end{array}$ & \\
\hline 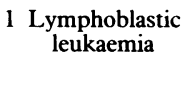 & $\begin{array}{l}\text { right eye: severe peripapillary } \\
\text { infiltration } \\
\text { left eye: moderate swollen disc, } \\
\text { seventh nerve palsy }\end{array}$ & Irradiation, chemotherapy & $18(16)$ & 32 & - \\
\hline 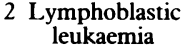 & Mild peripapillary infiltration & Irradiation, chemotherapy & 22 & 69 & + \\
\hline 3 Lymphoblastic & $\begin{array}{l}\text { Moderate swollen disc } \\
\text { seventh nerve palsy }\end{array}$ & Not done & $16(5)$ & 60 & + \\
\hline $\begin{array}{c}4 \text { Lymphoblastic } \\
\text { leukaemia } \\
\text { (T cell) }\end{array}$ & $\begin{array}{l}\text { Severe swollen disc } \\
\text { third, fourth, sixth nerve palsy }\end{array}$ & Irradiation not completed & $1(31)$ & 42 & - \\
\hline 5 Lymphoblastic & Mild swollen disc & Chemotherapy & More than 31 & More than 84 & + \\
\hline
\end{tabular}

( ) Survival after nerve palsy

Table 3 Survival of patients with anterior segment leukaemic infiltration

\begin{tabular}{|c|c|c|c|c|c|}
\hline \multirow[b]{2}{*}{ Type } & \multirow[b]{2}{*}{ Ophthalmic findings } & \multirow[b]{2}{*}{$\begin{array}{l}\text { Treatment for } \\
\text { the eye }\end{array}$} & \multicolumn{2}{|c|}{ Survival (months) } & \multirow[b]{2}{*}{$\begin{array}{l}5 \text { year } \\
\text { survival }\end{array}$} \\
\hline & & & $\begin{array}{l}\text { After ocular } \\
\text { manifestation }\end{array}$ & $\begin{array}{l}\text { After onset } \\
\text { of leukaemia }\end{array}$ & \\
\hline $6 \begin{array}{c}\text { Monocytic } \\
\text { leukaemia }\end{array}$ & $\begin{array}{l}\text { Hypopyon, keratic precipitate, } \\
\text { seventh nerve palsy }\end{array}$ & Chemotherapy & $1(7)$ & 9 & - \\
\hline 7 Lymphoblastic & $\begin{array}{l}\text { Hypopyon, seventh nerve palsy, } \\
\text { vitreous and retinal haemorrhage }\end{array}$ & Chemotherapy & $4(1)(1)$ & 16 & - \\
\hline 8 Monocytic & Hyphaema, hypopyon, glaucoma & Chemotherapy, irradiation & 10 & 19 & - \\
\hline $9 \begin{array}{r}\text { Myeloblastic } \\
\text { leukaemia }\end{array}$ & $\begin{array}{l}\text { Keratic precipitate, cells in anterior } \\
\text { chamber, retinal haemorrhage, } \\
\text { cotton wool spot }\end{array}$ & Chemotherapy & $19(17)$ & 20 & - \\
\hline
\end{tabular}

( ) Survival after nerve palsy or retinal haemorrhage

Table 4 Survival of patients with orbital leukaemic infiltration

\begin{tabular}{|c|c|c|c|c|c|}
\hline \multirow[b]{2}{*}{ Type } & \multirow[b]{2}{*}{ Ophthalmic findings } & \multirow[b]{2}{*}{$\begin{array}{l}\text { Treatment for } \\
\text { the eye }\end{array}$} & \multicolumn{2}{|c|}{ Survival (months) } & \multirow[b]{2}{*}{$\begin{array}{l}5 \text { year } \\
\text { surviva }\end{array}$} \\
\hline & & & $\begin{array}{l}\text { After ocular } \\
\text { manifestation }\end{array}$ & $\begin{array}{l}\text { After onset } \\
\text { of leukaemia }\end{array}$ & \\
\hline $10 \begin{array}{c}\text { Myeloblastic } \\
\text { leukaemia }\end{array}$ & Severe proptosis & Irradiation, chemotherapy & 15 & 15 & - \\
\hline 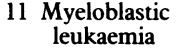 & Mild proptosis, retinal haemorrhage & Irradiation, chemotherapy & $7(7)$ & 29 & - \\
\hline 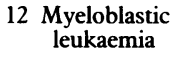 & Mild proptosis & Chemotherapy & 10 & 10 & - \\
\hline
\end{tabular}

( ) Survival after retinal haemorrhage.

(23 cases), and (2) retinal haemorrhages and other vascular changes (13 cases). With direct leukaemic infiltration, four patterns occurred; optic nerve infiltration (five cases), anterior segment uveal infiltration (four cases), orbital infiltration (three cases), and neuro-ophthalmic sign of central nervous system leukaemia (16 cases), which included cranial nerve palsy and papilloedema. The retinal haemorrhages and other vascular changes were the results of haematological disorders. These included retinal or vitreous haemorrhage (11 cases), cotton wool spot (three cases), and tortuous vessels (one case). In the present study, bilateral disc oedema with increased intracranial pressure and no evidence of leukaemic cell infiltration was defined as a neuro-ophthalmic sign of central nervous system leukaemia. Unilateral swelling of the optic nerve head without evidence of elevated intracranial pressure was defined as retrolaminar optic nerve infiltration. The numbers of patients with each type of leukaemia are shown in Table 1. Eleven patients had more than two ophthalmic abnormalities. Direct leukaemic infiltration was treated by systemic chemotherapy and in some instances with intrathecal antileukaemic agents. Irradiation therapy specific to the eye was performed in six patients with leukaemic ophthalmic infiltration. Two patients who had optic nerve infiltration could not receive complete radiation therapy; one patient died during treatment, and the other showed leucoencephalopathy, a side effect of radiation therapy. Among 28 patients with ophthalmic manifestations, 23 $(82 \cdot 1 \%)$ experienced central nervous system leukaemia. All of the patients with ophthalmic manifestations experienced either central nervous system leukaemia or bone marrow relapse during the entire course of leukaemia.

Twenty seven $(96.4 \%)$ of 28 patients died within 28 months from the onset of ophthalmic manifestations and within 83 months from the onset of leukaemia. The survival periods ranged from 15 days to 31 months after the onset of ophthalmic manifestation of leukaemia.

The 5 year survival rate for the 28 patients was $6 / 28(21 \cdot 4 \%)$. This was significantly lower than the rate for those who lacked ocular manifestations $(16 / 35,45 \cdot 7 \% \mathrm{p}<0.05)$.

Four of five patients with optic nerve 
infiltration, died within 22 months and one patient who had moderate optic disc swelling without the evidence of nerve head infiltration is still alive more than 31 months after the onset of ocular involvement (Table 2). The survival periods from the onset of leukaemia ranged from 32 to more than 84 months. The average survival period was 50.8 months.

All of the patients with anterior segment uveal infiltration died within 19 months from the onset of leukaemia (Table 3). The average survival periods were 8.5 months from the onset of ocular manifestation, and 16.0 months from the onset of leukaemia.

All the patients with orbital infiltration died within 15 months from the onset of leukaemia (Table 4). The average survival period of the patients was $18 \cdot 0$ months.

In 16 patients with neuro-ophthalmic signs of central nervous system leukaemia, 11 who had no evidence of infiltration of the optic nerve or other ocular tissues, died within 28 months from the onset of leukaemia (Table 5). Nine patients who developed ocular manifestation with central nervous system recurrence, not as an initial symptom of leukaemia, all died within 7 months from the onset of ocular manifestation. The average survival period of those nine patients was $4 \cdot 1$ months from the onset of ocular manifestation.

All 13 patients with retinal haemorrhages or other vascular changes died within 17 months of

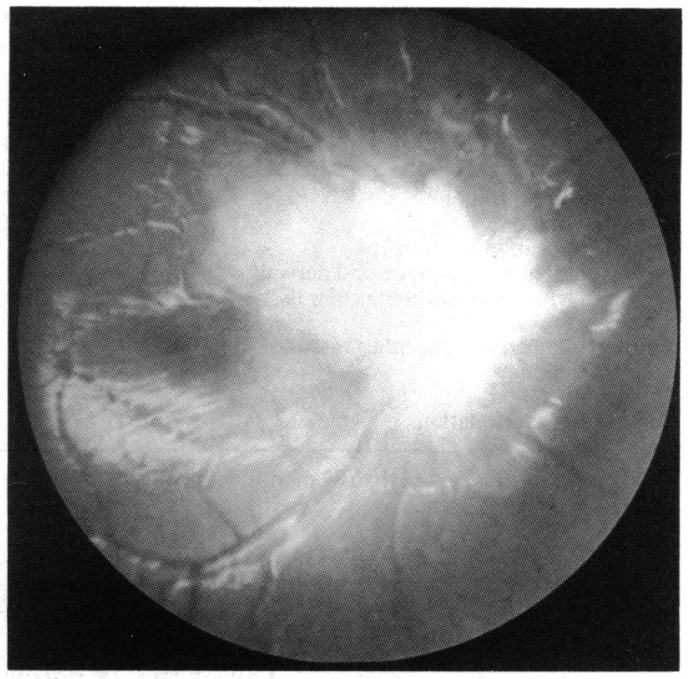

Figure 1 Extensive leukaemic infiltration to the optic nerve head in a patient with acute lymphoblastic leukaemia.

the identification of ocular manifestations. Five of these 13 patients, who presented with retinal haemorrhages or vascular changes alone, died within 12 months of identification of these ocular manifestations (Table 6). Ten of those 13 patients presented with retinal or vitreous haemorrhages at the time of bone marrow relapse not at the time of the initial induction treatment. All of these patients died within 9 months after developing

Table 5 Survival for patients with neuro-ophthalmic sign with central nervous system leukaemia

\begin{tabular}{|c|c|c|c|c|}
\hline \multirow[b]{2}{*}{ Type of leukaemia } & \multirow[b]{2}{*}{ Ophthalmic findings } & \multicolumn{2}{|c|}{ Survival (months) } & \multirow[b]{2}{*}{$\begin{array}{l}5 \text { year } \\
\text { survival }\end{array}$} \\
\hline & & $\begin{array}{l}\text { After ocular } \\
\text { manifestation }\end{array}$ & $\begin{array}{l}\text { After the onset } \\
\text { of leukaemia }\end{array}$ & \\
\hline 13 Lymphoblastic & Third nerve palsy, papilloedema & 2 & 12 & - \\
\hline $14 \begin{array}{l}\text { Erythro- } \\
\text { leukaemia }\end{array}$ & Seventh nerve palsy & 4 & 5 & - \\
\hline 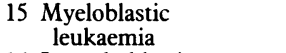 & Third, seventh nerve palsy & 17 & 17 & - \\
\hline $\begin{array}{l}16 \text { Lymphoblastic } \\
\text { leukaemia }\end{array}$ & Seventh nerve palsy & 7 & 20 & - \\
\hline $17 \begin{array}{l}\text { Lymphoblastic } \\
\text { leukaemia (T cell) }\end{array}$ & Seventh nerve palsy & 5 & 14 & - \\
\hline $\begin{array}{l}18 \text { Lymphoblastic } \\
\text { leukaemia }\end{array}$ & Seventh nerve palsy, papilloedema & 2 & 18 & - \\
\hline 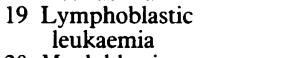 & Papilloedema, retinal haemorrhage & $7(7)$ & 83 & + \\
\hline $20 \begin{array}{c}\text { Myeloblastic } \\
\text { leukaemia }\end{array}$ & $\begin{array}{l}\text { Seventh nerve palsy, papilloedema, } \\
\text { tortuous vein }\end{array}$ & 5 & 50 & - \\
\hline 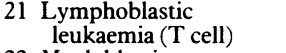 & Seventh nerve palsy, retinal haemorrhage & $1(1)$ & 18 & - \\
\hline 22 Myeloblastic & $\begin{array}{l}\text { Seventh nerve palsy, retinal haemorrhage, } \\
\text { cotton wool spot }\end{array}$ & $28(1)$ & 28 & - \\
\hline 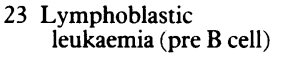 & Seventh nerve palsy, macular haemorrhage & $4(1)$ & 14 & - \\
\hline
\end{tabular}

( ) survival period after retinal haemorrhage

Table 6 Survival for patients with retinal haemorrhages or other vascular changes

\begin{tabular}{|c|c|c|c|c|}
\hline \multirow[b]{2}{*}{ Type } & \multirow[b]{2}{*}{ Ophthalmic findings } & \multicolumn{2}{|c|}{ Survival (months) } & \multirow[b]{2}{*}{$\begin{array}{l}5 \text { year } \\
\text { survival }\end{array}$} \\
\hline & & $\begin{array}{l}\text { After ocular } \\
\text { manifestation }\end{array}$ & $\begin{array}{l}\text { After the onset } \\
\text { of leukaemia }\end{array}$ & \\
\hline $24 \begin{array}{r}\text { Myeloblastic } \\
\text { leukaemia }\end{array}$ & Vitreous haemorrhage & 9 & 48 & - \\
\hline 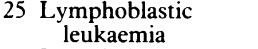 & Cotton wool spot & 12 & 74 & + \\
\hline $\begin{array}{c}26 \text { Lymphoblastic } \\
\text { leukaemia }\end{array}$ & Retinal haemorrhage & $0 \cdot 5$ & 60 & + \\
\hline $27 \begin{array}{c}\text { Lymphoblastic } \\
\text { leukaemia }\end{array}$ & Retinal haemorrhage & 1 & 5 & - \\
\hline $\begin{array}{l}28 \text { Lymphoblastic } \\
\text { leukaemia (T cell) }\end{array}$ & Massive retinal and preretinal haemorrhage & 2 & 18 & - \\
\hline
\end{tabular}


Table 7 Average survival and standard deviation of patients with ocular manifestations

\begin{tabular}{|c|c|c|c|}
\hline & \multicolumn{2}{|c|}{ Survival (months) $(S D)$} & \multirow[b]{2}{*}{$\begin{array}{l}5 \text { year survival } \\
\text { rate }(\%)\end{array}$} \\
\hline & $\begin{array}{l}\text { After ophthalmic } \\
\text { manifestation }\end{array}$ & $\begin{array}{l}\text { After onset of } \\
\text { of leukaemia }\end{array}$ & \\
\hline $\begin{array}{l}\text { Optic nerve infiltration } \\
\text { Uveal infiltration } \\
\text { Orbital infiltration }\end{array}$ & $\begin{array}{r}14 \cdot 3(7 \cdot 9) \\
8 \cdot 5(6 \cdot 9) \\
10 \cdot 6(3 \cdot 3)\end{array}$ & $\begin{array}{l}50 \cdot 8(14 \cdot 5) \\
16 \cdot 0(4 \cdot 3) \\
18 \cdot 0(8 \cdot 0)\end{array}$ & $\begin{array}{l}3 / 5(60) \\
0 / 4(0) \\
0 / 3(0)\end{array}$ \\
\hline $\begin{array}{l}\text { system leukaemia (without ocular tissue } \\
\text { infiltration) } \\
\text { Retinal haemorrhage and other vascular }\end{array}$ & $7 \cdot 4(7 \cdot 7)$ & $25 \cdot 4(21 \cdot 3)$ & $1 / 11(9 \cdot 1)$ \\
\hline $\begin{array}{l}\text { changes alone } \\
\text { Tissue infiltration } \\
\text { Any ocular manifestation }\end{array}$ & $\begin{array}{l}4 \cdot 9(4 \cdot 7) \\
9 \cdot 3(7 \cdot 6) \\
8 \cdot 5(7 \cdot 3)\end{array}$ & $\begin{array}{l}41 \cdot 0(25 \cdot 8) \\
27 \cdot 3(20 \cdot 3) \\
29 \cdot 8(22 \cdot 1)\end{array}$ & $\begin{array}{l}2 / 5(40 \cdot 0) \\
4 / 23(17 \cdot 4) \\
6 / 28(21 \cdot 4)\end{array}$ \\
\hline
\end{tabular}

One case who is alive more than 84 months was excluded

these haemorrhages, the average survival period being $3 \cdot 1$ months.

Ten of the 28 patients $(35 \cdot 7 \%)$ had decreased vision; three optic nerve infiltration, three anterior uveal infiltration, one orbital infiltration, and three with vitreous, preretinal, or macular haemorrhage. All of these patients died within 1 to 19 months from the onset of visual impairment.

\section{Discussion}

Childhood leukaemia, $95 \%$ of which is acute, has a better prognosis than adult leukaemia. In children acute lymphoblastic leukaemia accounts for approximately $70 \%$ of all cases. With current sophisticated treatment regimens, this form of leukaemia has a cure rate greater than $60 \%$. The predominance of acute lymphoblastic leukaemia in children and its excellent prognosis is the major reason for the difference in survival rate between childhood and adult leukaemia. Many patients, however, still suffer from relapse and are unlikely to achieve a complete cure. The presence of ophthalmic findings in childhood leukaemia is well known. Since modern chemotherapy was introduced, however, very few attempts have been made to relate the prognosis of the disease to ophthalmic manifestations.

In 1976 , Ridgway et $a l^{4}$ reported that $80 \%$ of children died within 10 months following ocular complications in acute leukaemia. In 1989, Lo Curto et $a l^{10}$ reported that six of 38 patients with leukaemic ophthalmopathy achieved continuing complete remission. These two studies, however, did not indicate the prognosis, because the observation period was short or unclear.

The present study revealed that $96 \cdot 4 \%$ (27/28) of children with acute leukaemia died within 28 months from the onset of ocular manifestations. Accordingly, this suggests that there is very little possibility for leukaemic patients with ocular manifestations to achieve complete cure even with modern treatment methods. One patient, however, is still alive. Lo Curto et $a l^{10}$ reported on the potential of long term complete remission (more than 78 months) in patients with isolated leukaemic ophthalmopathy. These facts may suggest that there is a possibility for patients with ophthalmic involvement to achieve a cure. An aggressive treatment to the eye, therefore, is recommended, not only to protect vision but also to attain a long term remission. We expect that today's more sophisticated treatment may improve the prognosis of patients with ophthalmic manifestations.

The 5 year survival rate for patients with ophthalmic manifestations was lower than for those patients who lacked ocular manifestations. This suggests that the presence of ophthalmic manifestations may be one of the factors which shorten the survival period.

There are two major causes of ocular involvement; tissue infiltration of leukaemic cells and bone marrow dysfunction which causes anaemia and/or thrombocytopenia. In our patients with lymphoblastic leukaemia, most of the ophthalmic tissue infiltration was related to central nervous system leukaemia. Central nervous system involvement is one of the most serious complications which leads to a poor prognosis in acute leukaemia. The period of haematological remission is reduced by central nervous system leukaemia, which is almost inevitably followed by bone marrow relapse. "In the present study, 14 of $17(82 \cdot 4 \%)$ acute lymphoblastic patients with ophthalmic manifestations had central nervous system leukaemia. This incidence was higher than in those who lacked ocular manifestations $(9 / 35: 25 \cdot 7 \%)$. The higher incidence of central nervous system leukaemia in patients with ophthalmic manifestations may be one of the factors which shortens the survival period.

Bone marrow dysfunction, on the other hand, is another cause of ophthalmic involvement. This can be seen at the onset of leukaemia but is more prominent at the time of bone marrow relapse. Most patients who had bone marrow relapse experience subsequent relapse and eventually die, even though first remission rate is $85 \%^{12}$ in acute lymphoblastic leukaemia. Therefore, bone marrow relapse is another factor which shortens the survival period. In the present study, all of the patients with ophthalmic manifestations had either bone marrow relapse or central nervous system leukaemia. Both of these problems, rather than ophthalmic manifestations themselves, we assume, influenced the survival period.

Çavdar et $a l^{13}$ have reported that an ocular manifestation was asssociated with a poor prognosis. They reported that the mean survival rate in patients with acute myeloblastic leukaemic and orbito-ocular granulocytic sarcoma was significantly lower ( 8.7 months) than in those without orbito-ocular granulocytic sarcoma (28.6 months) after similar treatment. In the present study, the survival periods of the patients with extramedullary infiltration such as anterior segment uveal infiltration or orbital infiltration were extremely low. These facts suggest that extramedullary infiltration other than central nervous system leukaemic cell infiltration may influence the prognosis of acute non-lymphoblastic leukaemia.

Among ophthalmic manifestations, optic nerve infiltration is thought to be a partial presentation of central nervous system leukaemia. Although both optic nerve infiltration and the neuro-ophthalmic sign of central nervous system leukaemia have the same pathogenesis, in our patients these two disorders had quite different prognoses. The average survival 
period for patients with optic nerve infiltration was 50.8 months from the onset of leukaemia, and $60 \%$ of patients survived more than 5 years. In contrast the average survival period for patients with the neuro-ophthalmic signs of central nervous system leukaemia without any other ocular tissue infiltration was 25.4 months from the onset of leukaemia, and the 5 year survival rate was only $9 \cdot 1 \%$ (Table 7 ). These results suggest that although both processes have the same pathogenesis, neuro-ophthalmic complications may represent a more advanced process, or greater systemic involvement than optic nerve infiltration.

Patients with neuro-ophthalmic signs of central nervous system leukaemia and patients with retinal or vitreous haemorrhages at the time of relapse died within a very short period (average of $4 \cdot 1$ and $3 \cdot 1$ months respectively). These two ocular manifestations, when identified in either central nervous system relapse or bone marrow relapse, suggested a very poor prognosis. The patients who presented with these findings at the time of the initial diagnosis survived longer. This reflects the fact that the remission rate at the time of relapse is lower than the rate at initial induction therapy. This may be related to the tolerance of antileukaemic agents.

This study demonstrated that the presence of ocular involvement with a poor prognostic sign in acute childhood leukaemia. The prognosis, however, was related to risk factors such as central nervous system leukaemia or bone marrow relapse. Some ophthalmic manifestations such as neuro-ophthalmic signs of central nervous system leukaemia, or retinal haemorrhages may be poor prognostic signs if they are seen in the relapse period. Ophthalmic examination in the relapse period, therefore, may be of some value in predicting survival.

We acknowledge the support of the Department of Pediatrics, St Luke's International Hospital and the Juntendo University Hospital.

1 Borgeson EJ, Wagener HP. Changes in the eye in leukemia. Am F Med Sci 1929; 177: 663-76.

2 Culler AM. Fundus changes in leukemia. Trans Am Ophthalmol Soc 1951; 49: 445-73.

3 Allen RA, Straatsma BR. Ocular involvement in leukemia and allied disorders. Arch Ophthalmol 1961; 66: 490-508.

4 Ridgway EW, Jaffe N, Walton DS. Leukemic ophthalmopathy in children. Cancer 1976; 38: 1744-9.

5 Kincaid MC, Green WR. Ocular and orbital involvement in leukemia. Surv Ophthalmol 1983; 27: 211-32.

6 Ohkoshi K. Ocular manifestations of childhood leukemia. Acta Soc Ophthalmol fpn 1988; 92: 1787-96.

7 Schachat AP, Markowitz JA, Guyer DR, Burke PJ, Karp JE, Graham ML. Ophthalmic manifestations of leukemia. Arch Ophthalmol 1989; 107: 697-700.

8 Leonardy NJ, Rupani M, Dent G, Klintworth GK. Analysis of 135 autopsy eyes for ocular involvement in leukemia. $A m \mathcal{F}$ Ophthalmol 1990; 109: 436-44.

9 Mahneke A, Videbæk A. On changes in the optic fundus in leukemia. Acta Ophthalmol (Kbh) 1964; 42: 201-10.

10 Curto MLo, Zingone A, Acquaviva A, Bagnulo S, Calculli L, Cristiani L, et al. Leukemic infiltration of the eye: Results of therapy in a retrospective multicentric study. Med Pediatr Oncol 1989; 17: 134-9.

11 Bleyer WA. Central nervous system leukemia. Pediatr Clin $N$ Am 1988; 35: 789-811.

12 Poplack DG, Reaman G. Acute lymphoblastic leukemia in childhood. Pediatr Clin N Am 1988; 35: 903-32.

13 Çavder AO, Babacan E, Gözdaşoğlu S, Kilicturgay K, Arcasoy $\mathrm{A}, \mathrm{Cin} \mathrm{S}$, et al. High risk subgroup of acute myelomonocytic leukemia (AMML) with orbito ocular granulocytic sarcome (OOGS) in Turkish children. Acta Haematol 1989; 81: 80-5. 